Vol. 1, nº 1 | 1997

Varia

\title{
Crime, Justice and Society in Medieval and Early Modern Times : Thirty Years of Crime and Criminal Justice History
}

A tribute to Herman Diederiks

Xavier Rousseaux

Translator. Kevin Dwyer

\section{OpenEdition}

Journals

Electronic version

URL: https://journals.openedition.org/chs/1034

DOI: $10.4000 /$ chs. 1034

ISSN: 1663-4837

Publisher

Librairie Droz

Printed version

Date of publication: 1 January 1997

Number of pages: 87-118

ISSN: $1422-0857$

Electronic reference

Xavier Rousseaux, "Crime, Justice and Society in Medieval and Early Modern Times : Thirty Years of Crime and Criminal Justice History", Crime, Histoire \& Sociétés / Crime, History \& Societies [Online], Vol. 1, $\mathrm{n}^{\circ} 1$ | 1997, Online since 03 April 2009, connection on 30 September 2021. URL: http:// journals.openedition.org/chs/1034 ; DOl: https://doi.org/10.4000/chs.1034 


\title{
Crime, Justice and Society in Medieval and Early Modern Times:
} Thirty Years of Crime and Criminal Justice History

\author{
A tribute to Herman Diederiks'
}

\section{Xavier Rousseaux}

Historians are part of the existing world and in their intellectual endeavour they bring forward questions for past times that are derived from their present situation ${ }^{2}$.

\section{THE HISTORIOGRAPHY OF CRIME AND CRIMINAL JUSTICE: NEW WINE IN OLD FLASKS}

The historiography of the variety of subjects which are grouped under the 1 generic term «History of Crime and Criminal Justice» is not easy to unravel. As a relatively new area of history, this sub-discipline does not have any long-established tradition, nor any institutional points of reference, nor any specialised research implements at its disposal.

The first organised study group to appear in the area was the Nederlandse Werkgroep Strafrechtgeschiedenis, founded in 1973 notably by Herman Diederiks. The group organised two international meetings in 1977 in Amsterdam and Leiden devoted to the history of crime ${ }^{3}$, and another at the Economic and Social History Conference in Edinburgh in $1978^{4}$. Following on from these, the International Association for the History of Crime and Criminal Justice was established as became the first regular meeting point of researchers who until then had been dispersed in various branches of history - as well as combining institutional and legal, economic and social, political, anthropological and cultural, with the practices of other researchers in the social sciences (jurists, criminologists, sociologists, anthropologists). Between 1978 and 1995, the association organised a number of «intercontinental» conferences and about twenty thematic colloquia, which mainly took place, most appropriately, at the Maison des Sciences de l'Homme in Paris. They also began publishing a Newsletter in 1972 , subsequently called the Bulletin ${ }^{5}$.

1 A shorter version of this article was presented at the First European Social Science History Conference at Noordwijkerhout, the 11th may 1996, during the Herman Diederiks Memorial Session.

2 Diederiks (1995, p.16).

3 Diederiks, Faber (1978, p. 105).

4 Criminal Justice History, 1980, I.

5 IAHCCJ-Newsletter, IAHCCJ-Bulletin. 
In a short time, signs of maturity in this new research domain have multiplied, extending from the creation of national networks of Crime and Criminal Justice historians as in Germany ${ }^{6}$, to international networks created within associations such as the Social Science History Association to specialised sessions at international meetings such as the recent International Congress of Historical Sciences ${ }^{7}$ or the newlycreated European Social Science History Conference, and, finally, to specialised journals and reviews.

Nevertheless, many specialists in the social sciences still consider crime as a marginal or temporary subject of research, and this has sometimes impeded growth in the area. A good indication of this problem is the current low number of scientific studies, as recently pointed out by L. Knafla ${ }^{8}$. On a national level England is exceptional, with the respective volumes of J. Sharpe and C. Emsley, which might serve as models for future work. As for international efforts, the oft-cited work of Weisser remains inadequate ${ }^{9}$. Moreover, the history of crime has not yet achieved full integration within general history.

If comprehensive analyses have been slow to appear, this is doubtless linked to the number of theses devoted to the subject. In many countries, university courses exploring the history of crime are on the increase; but doctorates are far less numerous, thus delaying the emergence of solidly-documented and intellectually sound studies and handicapping the institutionalisation of research in this area in universities and other scientific institutions. These limitations are the direct consequence of both the intellectual openness and the high quality of research carried out so far in this field. The history of crime and criminal justice can in fact be credited to a number of different «fathers»: crime history is not only directly related to institutional and legal history, but also to economic and social history, to anthropological and cultural history, and to political history.

\section{Institutional and Legal History: Looking for the State}

Studies in institutional history have often been limited to statistical and genealogical research, focusing on the origins of institutions and their competences. The history of law, on the other hand, has mainly concentrated on pre-19th century periods and has followed the same pattern: national readings with research into the original character of «popular» law. Jurists conceived such histories with the matrix of contemporary law in mind, guided by the presumption of the uniformity of state law and the primacy of norms over practices, and of legal forms over strategies. This resulted in a history of law that was difficult to integrate into general history because it was too close to a widely-held triumphalist view of the law and legality. It is precisely such views that have been brought to question in the past thirty years. For any jurist with critical acumen, doubt has become the norm. Crises in state law, the multiplicity of norms and sources when it comes to law, and the realisation of the ponderousness of legal practices and the hypocrisy of procedures and strategies have pounded gaping holes in the very foundations of law. Young jurists, especially those

\footnotetext{
6 Sack (1987); Smaus (1987); Romer (1992); Schwerhoff (1992); Thome (1992); Blauert, Schwerhoff (1993); Eibach (1996).

7 Rousseaux, Emsley (1995).

8 Knafla (1996, p. 33).

9 Weisser (1982).
} 
oriented towards the social sciences such as criminologists, philosophers, sociologists, anthropologists and legal historians, have all settled down to the task of reexamining legal phenomena as they are rooted in social systems. This new breed of legal historian has particularly found expression in the history of Medieval and Early Modern penal law. As a result, in the course of the 1970s they became more frequently associated with economic and social historians ${ }^{10}$.

\section{Economic and Social History: The Quest for Social Production}

The prodigious development of economic and social history in the 1960 s focused particularly on modern history - extending from the development of commercial capitalism in the 16th century to the emergence of industrial capitalism in the mid-19th century. Many schools of thought on the continent were essentially founded on the premises of urban economic history ${ }^{11}$, to which Herman Diederiks was a significant contributor, but there was also important research on the structure of rural societies, and a number French doctorates in this outstanding domain ${ }^{12}$. Here we can find the undeniable traces of the original Annales project - a total history founded on the notion of using statistics as expressions of rationality - based on the tension resulting from a necessarily rational distribution of wealth and the circulation of profits solely among capitalist entrepreneurs. Within this demographic and economic paradigm of a social history of poverty ${ }^{13}$, researchers came across rewarding sources in judicial archives revealing the fascinating existence of the mass of delinquents who were habitually rounded up in the event of major or minor infractions ${ }^{14}$. Researchers began to contemplate a quantitative history of crime that gives privileged access to the study of those who had been omitted from most other histories ${ }^{15}$. But in the England of the Welfare State, the direction taken was rather different. Under the impulse of more overtly leftist trends in social history, researchers not only became interested in the living conditions of the masses, but also in the Common Law tradition that was increasingly in the hands of political parties and in the manipulation of the law and justice systems by the ruling classes. A history thus arose that was more social than economic, attentive not only to conflicts between ruling and «popular» classes, but also to conflicts within social groups. French research, in constrast, was more oriented towards a history shaped by the relationship between populations and economic pressure, and focused on the phenomenon of social exclusion (i.e., the poor and marginal classes).

\section{Political History: Looking for the Roots of Power}

Traditional political history, considered as too preoccupied by the outward appearance of things, was discredited in France by the Annales programme, which itself was more concerned with Braudelian approaches to history, with emphasis on socio-economic structures and mental archeo-structures ${ }^{16}$. Although political his-

\footnotetext{
10 Faber (1983); Schnapper (1991).

11 Chaunu (1959); van der Wee (1963); De Vries (1974).

12 Goubert (1960); Bois (1960); Le Roy Ladurie (1966).

13 Mollat (1974).

14 Bercé, Castan (1990)

15 Le Roy Ladurie (1973); Chaunu (1981).

16 Braudel (1949).
} 
tory has become caricaturised, much like the histories of battles and royal weddings, it has nonetheless continued to exist, evolving towards a careful examination of the mechanisms of domination. The current crisis of state-based models of government in the West has enlarged the problematic of political analysis, focussed for too long on electoral or revolutionary phenomena, and has permitted a re-examination of the multiple forms of domination in complex societies. From Weber to Foucault, 20th century researchers have furrowed their brows over the myriad aspects of power from the village to the court, in the city and the state. Following Charles Tilly, in the tradition of research on the mechanisms of domination, Medieval and Early Modern political history has focused on two key problematics of the state: the genesis of states, and the durability of state mechanisms through periods of political crisis (e.g. revolutions and dictatorships). These two issues required the use of long-term analysis. Crime and criminal justice seemed to play a fundamental role, although still far underestimated alongside military and economic factors ${ }^{17}$.

\section{Anthropological and Cultural History: Looking for People}

Final, more recent approach is deeply influenced by traditional anthropological examinations of the functioning of human societies in their ways of cooking, loving, dying, fighting or stealing. This is a history in which behaviour and mental reconstructions unveil the elementary structures of human activity. It was first assembled out of a corpus of literary and artistic expression, for example in the work of Huizinga, Elias or Aries. The mass of documentation on daily life found, notably, in judicial archives provided the primary material that enabled an elaboration of history inspired by the great anthropological work of Malinkowski and Lévi-Strauss. Studies of witchcraft comprise the most striking example of this form of anthropological history ${ }^{18}$. Combining the micro-histories of witch-burnings at village - or town-level with the macro-chronology of witch-hunts at the level of Western society during the 16th and 17th centuries, researchers arrived at a series of interpretations that called on various disciplines: anthropological research on witchcraft and myth in colonised or «archaic» societies, ethno-methodological or psycho-sociological work on inter-group relations, studies on collective representations (stereotypes, identities), and analyses of small-scale power.

Out of the convergence of these four broad historiographical traditions the first work that could be labelled as «Crime History" was born. First developed by French Early Modern historians (Le Roy Ladurie, Chaunu, Bercé, Yves \& Nicole Castan) and Anglo-Saxon social historians (Hobsbawm, Rude, Thompson, Tilly), this new field made a great impression on a whole generation of young European historians who met at the I.A.H.C.C.J.. The programme outlined in 1977 by H. Diederiks and S. Faber already contained the seeds of the main offshoots of the work of future generations: pluridisciplinarity, attention to problems of the definition of deviant behaviour, the concrete forms of «criminality» and the place of violence, the variety of punishments and the multiple forms of conflict resolution ${ }^{19}$. An initial assessment of the progress of research was made in 1990 on the occasion of the retirement of one of the founding fathers of the association, Y. Castan. The

17 Lévy, Rousseaux (1992).

18 Macfarlane (1970), Ginzburg (1973); Muchembled (1994).

19 Diederiks, Faber (1978). 
appraisal focussed on four areas in which the history of crime has served as a beacon: social relationships, mentalities, politics and law ${ }^{20}$. Six years later the publication of a series of national and regional assessments allowed us to compare the association's original programme with the actual achievements in the history of crime and criminal justice and these are discussed below under four separate headings ${ }^{21}$.

Very rapidly, young crime historians expressed themselves in the analytical framework forged by social and economic history, a history which relied mainly on serial sources. It will therefore first be necessary to say a few words in Part I about the specific sources of crime history and, naturally, about the new quantitative as well as qualitative methods these sources inspired. After rapidly reviewing these methods, Part II will examine some precise areas of criminal history and describe their major contributions to the field. From these partial results, Parts III and IV will attempt to analyse some of the links between the history of crime and the history of pre-industrial societies. Following on a suggestion made by J. Sharpe, this will take two directions. Firstly, in Part III, I will try to define the specificities of the influence of social history on criminal history in order to evaluate what the history of preindustrial societies has contributed to the history of crime and criminal justice. Then, in Part IV, I will reverser the question and ask what crime history can bring to the history of pre-industrial societies, i.e., what exactly is the influence of crime history on social history ${ }^{22}$.

The combination of new sources, new methods and renewed problematics has fostered a fruitful exchange between empirical research and theoretical debate. In my conclusion I will address the wider issue of the contribution of crime history's link to the history of societies to relations between the Social Sciences and the Humanities.

\section{1. - SOURCES AND METHODS}

The discovery of masses of judicial archives, whose serial nature remained unexplored for a long time, has given impetus to research which had otherwise been very impressionistic and which relied essentially on normative documents.

\section{a) Judicial Archives: New and Serial Sources}

Judicial archives have revealed a relatively unknown world, in which norms were observed and practised. The trials and sentences contained in the written archives of largely illiterate societies, where laws were for the most part local and practical, tarnish the clear and elegant image of ancient law as outlined in the scholarly work of jurists and legal historians.

The repetitive nature of both urban court and village notary records has encouraged a very different approach from that used by jurists. Instead of looking for the singularity of a procedure or technical solution, it has proved more revealing to examine the recurring structures of norms employed on a day-to-day basis. Tabulating the number of crimes, delinquents, sentences and court sessions soon became an

\footnotetext{
20 Coll. (1991).

21 Emsley, Knafla (1996).

22 Sharpe in Coll. (1991).
} 
everyday activity for historians, fascinated by the quality and density of so much information contained in various criminal archives ${ }^{23}$.

Although as of yet barely tapped, these archives have also revealed their limitation for historians who harboured a certain conception of state monopoly in matters of criminal justice. As they are from societies characterised by division and competition between different judicial institutions, these archives present a variety of prisms and partial views of the functioning of a given society. In some cases the analysis of various sources is not an insurmountable obstacle and it contributes positively to an understanding of both constructed nature of crime and the diversity of social viewpoints regarding crime. Furthermore, it was rapidly observed that many forms of behaviour slipped through the cracks of the justice system, which was often just one means among many to resolve conflicts. Outside of the justice system there existed multiple non-procedural methods of settling scores (such as private transactions or arbitration), many ways of cutting short court proceedings (appeasement, negotiating a settlement with court officers), or post-trial resolutions (such as royal clemency or pardon). Theses possibilities limited the potential of data based solely on judicial sources to provide a complete understanding of attitudes and responses to crime. In cases where practices have left written traces, such new sources have allowed for a more thorough study of the historical criticism of legal sources ${ }^{24}$.

Some of the limitations in the sources could be compensated by an analytical reorientation. By parting with the notion of crime in favour of the notion of repression, the problematic falls more in line with available sources, which all primarily evoke practices of institutional control rather than the reality of the behaviour that was being controled. This means that, once methodological and critical conclusions are drawn from this institutional analysis, one still must use prudence when investigating the behaviour that these sources reveal.

\section{b) Methodology: From Juridical Analysis to Cliometrics}

The methods of analysing these sources have greatly evolved over the years. A review of the literature reveals a number of possible approaches.

Focusing on the analysis of normative texts in order to find general rules that may be articulated around a coherent system, the classical juridical method has gained a lot from the exploitation of records of legal practices ${ }^{25}$. However, recourse to such records is still often regarded mainly as a matter of jurisprudence, as they are seen as providing solutions for problems that written law could not quite resolve. Certain legal historians have broken with this very literary approach and base their juridical assertions on quantitatively established data ${ }^{26}$. In this area, alongside crimes and criminals, juridical realities such as the number of cases dropped, judgement rates, the ratio of individuals prosecuted per case, the length of procedures, acquittal rates or the analysis of different judicial channels have all contributed to our knowledge of the mechanisms by which th law was applied.

Anthropological and sociological methods are currently renewing the study of these texts. As far as justice systems are concerned, the genealogical method favours

\footnotetext{
23 Bercé, Castan (1990); Bercé, Soman (1995).

24 Castan (1984); Spierenburg (1985).

25 Wijffels (1993).

26 Faber (1980).
} 
the questioning of both normative documents as well as records of events (such as trials and judgements), which together constitute a multi-layered corpus that creates a broad view of society as regulated by groups with diverging interests. It also became necessary to place the production of the archival documents themselves in their specific socio-political contexts. Such methods also seek to reconstitute the social networks (families, dependents) that come to the surface in trials and to examine the mental worlds of those involved, especially the accused ${ }^{27}$. The current fashion is to fabricate social micro-histories from the records of disputes or court proceedings ${ }^{28}$.

Moreover, these methods can be applied to the study of the material traces left behind by the social activity of conflict regulation. Iconology of justice and judicial archeology have contributed to two and three dimensional analyses of justice systems ${ }^{29}$.

Quantitative methods have also played a significant role in crime history over the past thirty years. The 1960 s and 1970s saw the reign of frequency tables, time series and histograms. Following the model set by economic and demographic history, historians tried to reconstruct both the structures (which explains the use of frequency tables producing raw figures and percentages) and the conjuncture (from which splendid chronological curves were drawn) of criminality. The stated objective was to combine these data with other socio-economic data, e.g. infanticide rates with infant mortality rates, theft of foodstuffs with grain prices, and the level of violence with demographic crises. The illusion of criminality as unique and uniform, the difficulty involved in combining data clearly constructed from autonomous representations with realities that depended on economic conjunctures, and the irritating under-representation of recorded data all quickly revealed the epistemological limitations of such methods. Unfortunately, despite solidly constructed studies such as Beattie's and the remarkable methodological work of Gatrell ${ }^{30}$, much research has continued to produce tables that are far from explicit, along with tautological ruminations on the «dark figure», which doubtless conceals many black holes.

Crime and criminal justice history have contributed to the development of new methods that are particularly oriented towards the internal analysis of regulatory systems. These have involved comparing prosecutions and actual sentences passed, distinguishing between different bell curves according to institutional practices and measuring the links between cases, individuals and sanctions. In short, this has meant studying the production of the conditions of social control, the police offices, the courts and the prisons, using methods that are similar to those used to study production in a factory. Economists currently use such methods, notably to assess of analysing the efficiency of public services or even the cost of crime; unfortunately, they do not always draw the same methodological and critical conclusions as crime historians. Among these methods, the techniques used in multi-varied analysis have been favoured. This technique allows one to draw up spreadsheets that can combine, for example, a series of «criminal» variables with a series of contextual and «social»

\footnotetext{
27 Ginzburg (1980).

28 Macfarlane (1970); Corbin (1990).

29

De Win (1992).

30

Gatrell (1980); Beattie (1986).
} 
variables ${ }^{31}$.These methods, perfected in crime statistics produced for the 19 th and 20th centuries, of which the most famous example is the "Compte général de l'administration de la justice criminelle française (1825-1981)», are applicable to research data based on the systematic investigation of serial archives ${ }^{32}$.

Finally, serial analysis methods have been thoroughly renewed since the late 1980s by economists, especially in the area of long series. These methods can be particularly useful to historians interested in long-term analysis ${ }^{33}$.

\section{c) From Quantitative to Qualitative: The Return of the Repressed}

Empirical research in this area generally tries to combine qualitative and quantitative analyses, thus giving an all-around view of the data under observation ${ }^{34}$. The validity of any quantitative undertaking must be based on the proper use of qualitative material, especially when dealing with problems of data definition and the choice of counting units, two areas that criminologists have found particularly difficult when it comes to crimes and sentences ${ }^{35}$. The researcher must justify the composition of his data (i.e., whether it is exhaustive or a sample) and the scope of both his chronology and methodology. Historians must also re-insert the figures either within the density of particular conflictual situations, through a very astute analysis of the social relationships at play in the conflict, or within more general interpretations based on the observation of empirical results ${ }^{36}$.

Bringing a number of methodologies into play, as long as they are coherent with the sources, the problematic in question and the complete context, allows the researcher to avoid the dead-end of an impressionistic analysis of figures that in themselves are not critical enough. The first attempts to trace the individual or social causes of crime ended in failure due to a lack of sufficient attention paid to the constructed nature of the data under examination. On the other hand, researchers who have tried, as faithfully as possible, to reconstruct the activities involved in crime control have provided a solid base for the exploration of links between factors of crime control and other social factors.

\section{II. - MAJOR CONTRIBUTIONS: FROM CRIME TO CRIMINAL POLICY}

The first contributions were inherited from quantitative history. This initially involved a rather naive rediscovery of crime and criminal «tables.» Paying hardly any attention to the status of information such as the designations of different offences and their authors, these tables aimed to evaluate crimes and offenders, much in the same way that prices, salaries, births, marriages and deaths have been tabulated. As a result the structure of criminality and the characteristics of criminals

Aubusson de Cavarlay et alii (forthcoming).

Aubusson de Cavarlay (1993).

Thome (1992); de la Croix, Rousseaux, Urbain (1996).

Beattie (1986); Shoemaker (1991).

Kitsuse, Cicourel (1963); Johnson (1990).

Thome (1992). 
were the first objects of study, while the structures of repression were left in the shadows for a long time.

\section{a) Patterns of Crime}

The global structures of crime are relatively well-established. From the outset, the small quantity of data and imprecise dates led more often than not to tables arranged by crime classification (violent crimes, theft, crimes against moral, religious or political order) and in chronological divisions of a few years. Numerous case studies for both the late Middle Ages and Early Modern period gave primacy of place to violent crimes in pre-industrial societies. The link between crimes against people and crimes against property is highly noticeable in descriptions of crime structure as of the 18th century. These two important factors gave birth to the famous violence-to-theft theory ${ }^{37}$.

\section{Violence}

The presence of physical violence in cities and the countryside led to debates about the meaning of violence and its evolution. The issue of homicide has been the subject of much debate. Was there really such a high rate of homicide in the Middle Ages? Was there indeed a decline in homicide from the 17th to the 19th centuries? Were Western societies more violent then than they are today? Is a decline in homicide a sign of a moral civilising process? The debate was particularly lively among American researchers, as well as among anthropologists of Southern hemisphere countries who were struck by the differing positions of homicide in American, Mediterranean and Continental societies ${ }^{38}$.

Other more banal forms of violence such as assault and insult were extremely notable in archives of pre-industrial societies without necessarily being part of the same debate. Research such as that carried out by Robert Muchembled on Early Modern Artois and Claude Gauvard on 14th century France has nonetheless endeavoured to situate all forms of violence in any given society on a continuum in order to measure violence as a symbolic expression of social relationships ${ }^{39}$.

\section{Theff}

Although not negligible, theft in the Middle Ages has been relatively little studied. On the other hand, it has been the object of much research on the 18th and early 19 th centuries ${ }^{40}$. Analysed either from a Marxist perspective, based on the famous study by Karl Marx on legislation concerning wood theft in Rhineland ${ }^{41}$, or from the perspective of changing sensibilities, theft is currently the subject of important studies being carried out in the context of the industrial revolution ${ }^{42}$. The interest in petty theft, already evoked by Michel Foucault with the term «illegalisms», has been

\footnotetext{
Rousseaux (1996).

38 Blok (1974); Wilson (1988).

39 Y.Castan (1974); Muchembled (1978); Dupont-Bouchat, Rousseaux (1989); Gauvard (1993). See also for Germany, Rummel in Blauert, Schwerhoff (1993, p. 86-136).
}

40 Farge (1974); Blasius (1975), Shoemaker (1991).

41 Lascoumes, Zander (1984), Mooser (1984),

42 Thompson (1975); Chaunu (1981). 
revived by interest in the role and symbolic import of uncivil behaviour in industrial societies in crisis ${ }^{43}$.

\section{Moral and Religious Crimes}

The history of crime has greatly renewed perspectives on crimes against religious and moral order by inserting them within a larger context. For the medieval period, the documents that have been preserved mainly involve heresy. The few trial records that exist today have made extraordinary contributions to our knowledge of local societies, as has been revealed by the media success of the Le Roy Ladurie study of Montaillou ${ }^{44}$. For the 16 th and 17 th centuries the religious question seemed inextricably linked to the question of moral authority. The schism within in Christianity after 1520 led to an increase in crimes of divine lèse-majesty in both secular and ecclesiastical jurisdictions, especially where Inquisitions were present. Witchcraft and sorcery now form well-known chapters of modern history. The facts are substantial and the chronology of the witch-hunt that ravaged Western Europe from 1530 to 1650 is well-established. Interpretations are many and various characterising repression as a means of disciplining traditional rural practices by the dominant intellectual culture, as an outlet for economic crises and social tensions, as an instrument for the construction of newly-formed lay and religious powers, or as a means of re-articulating the relationship between religion and power. All of these analyses have progressively contributed to explaining the outbreak, the rhythms, the loci and the decline of this vast entreprise of social purification ${ }^{45}$.

Sexual conduct has often been included among offences against religious order. Judicial archives are interesting in that they document not only the repression of sexual behaviour, but also, inversely, the tolerance exhibited toward certain practices $^{46}$. Judging by the lightness of fines and the frequency of cases recorded, the records of ecclesiastical jurisdictions and rural court pleas offer a new vision of clerical attitudes towards chastity and the wrong-doings of their married parishioners ${ }^{47}$.

The toughening of repression is appreciable in the Modern era. Records of ecclesiastical courts, reformed or Calvinist consistory courts, as well as Royal officers in France and the Netherlands, all confirm the greater attention paid by authorities to sexual «deviance.» The massive persecution of sodomites in 1731 served as a demonstration of the limits of traditional tolerance in the United Provinces and marks the beginning of this trend ${ }^{48}$. These tougher measures have been viewed in light of attempts by the bourgeois elite to civilise moral behaviour or to repress popular cultures ${ }^{49}$.

\section{Political Crime}

As for the generally vague category of political crime, it has especially been studied in relation to forms of power in times of crisis. The attention of researchers has

43 Foucault (1975); Lagrange (1995).

4 Le Roy Ladurie (1975); Moore (1987)

45 Dupont-Bouchat (1987), Castan (1979), Ankarloo-Henningsen (1990); Soman (1992), Muchembled (1994).

46 Schuster in Blauert, Schwerhoff (1993, p. 17-31).

47 Dufresne (1976).

48 Meer (van der) (1984).

49 Muchembled (1987). 
especially been attracted to riots and sedition in medieval city-states, treason against a prince or lèse-majesty, and opposition by political groups during great revolutionary waves. Opposition to city authorities and the frequent exile of those defeated in political battles, the symbolic role of regicide and the horror of the punishment inflicted, excessively emphasised in Foucault's interpretation of modern justice systems, the practice of exceptional and revolutionary jurisdictions at a time when legislation was trying to make everyone equal before the law and the courts and to extirpate the political from the judicial - all have been studied essentially in relation to political structures and, to a far lesser extent, in relation to criminal structures.

As a general rule, studies that privilege the analysis of crime first led to the formulation of a simple paradigm of psycho-sociological causes for individuals or groups who resort to acts of crime and then to the elaboration of more complex links between phenomena of deviance and issues of social control (the uniformisation of morals, the repression of popular behaviour patterns, and changes in mentalities (e.g., an increase in sensitivity toward violence), as well as the political transformations of social relationships (e.g., the de-personalisation and abstraction of power, the seizure of the state by the bourgeoisie) ${ }^{50}$.

\section{b) Patterns of Criminals}

As far as the sociology of deviants is concerned, certain social characteristics have been highlighted repeatedly as explanations for individual resorting to crime. These include what might be called gender conditioning, age groups, and the labelling and identification of prosecuted «delinquents».

\section{Men and Women}

Most work has been concerned with the respective places of men and women in relation to criminality in the perspective of gender history. The under-representation of women among those prosecuted in different jurisdictions seems is partly compensated by their relative over-representation in specific types of offence such as prostitution, infanticide, witchcraft, adultery and poisoning; but they were also participants in grain riots. A number of studies have drawn attention to the stereotypical character of this behaviour, which is not as statistically frequent in archives as it is in literary sources or in the mental reconstructions of our contemporaries. On the other hand, particular attention must be paid to the position of women in a social environment in which conduct such as taking sides with men in their quarrels, committing minor misdemeanours or domestic theft, especially of food, could lead to the intervention of the justice system. Their position as the preferred victims in certain cases (e.g., sexual aggressions or rape) sheds light on their social position and is linked to their general exclusion from the personnel of the institutions that maintain social order.

\section{Youths and Age Groups}

Analysis in terms of age poses methodological problems of another nature. Apart from the fact that the age of offenders is not always mentioned in records, it is difficult to appreciate the significance of age for periods preceding the 18 th century. 
Nevertheless, the analysis of criminal behaviour relating specifically to youths such as infanticide, sexual violence, and juvenile delinquency has contributed to thinking on the progressive emergence, via laws, practices and public opinion, of the very notions of youth, childhood and adolescence ${ }^{51}$. Furthermore, the important role of unmarried youths in the life of local communities has been underlined for the Middle Ages and the Early Modern period (especially in regards to prostitution, collective rape, marriage policies and political protest $)^{52}$. A link has thus been established between traditional forms of youth associations and the emergence of political groups in revolutionary periods ${ }^{53}$.

\section{Inhabitants, Marginals and the Poor}

Societal integration and exclusion form yet another determining social element. The very different positions within the web of justice systems of long-standing inhabitants, newly-arrived inhabitants, migrants, and outcasts (such as vagrants and the unemployed) have been mainly studied as urban phenomena. In many instances it does not seem that their behavior differed much from that of the criminal stereotypes to which they would give rise: the vagrant, the thief, the travelling salesman, the female thief, the witch, and the prostitute. Here once again there has been an evolution from a relatively simple view of the psycho-social mechanisms commonly believed to explain the behaviour of marginals or deviants, to the multiple associations at interpersonal and collective levels revealed by the traumatic event labelled as "crime» ${ }^{54}$; Judicial archives have allowed researchers to refine the history of social groups, their inter-relations and the construction of the mechanisms that identify them.

\section{c) Patterns of Repression}

The study of repression has been recently renewed. In the 1960 s some researchers, fascinated with crime, largely ignored the measures of its repression. Contemporary studies now distinguish between prosecuted delinquents and those who have effectively received punishment following judicial proceedings. This history of repression, which a recent session of the International Congress of Historical Sciences summarised ${ }^{55}$, allows researchers to depart from historiographical notions that were too influenced by general stereotypes of the barbarism of punishments before the 19th century. The typology established by Rushe and Kirchheimer could be followed in order to distinguish three types of punishment that were successively used according to three social configurations of repressive societies ${ }^{56}$.

\section{Fines}

Interest in fines and financial penalties, which have often been neglected in research, has been rekindled by the important role they played in the regulation of

\footnotetext{
5I Egmond (1993b).

52 Otis (1985); Rossiaud (1988).

53 Agulhon (1970 a, b).

54 Hanawalt (1995).

35 Rousseaux, Emsley (1995).

56 Rusche, Kirchheimer, (1939).
} 
medieval conflicts. Other more original penalties, such as redeemable judicial pilgrimages, have allowed some to venture the notion of a penal fiscal economy, notably in medieval cities. This research has been of interest to those modern penologists who are concerned about both efficiently applying financial sanctions in legal cases in which money is the motive (such as financial lawsuits, the repression of clandestine traffic and economic delinquency), and about the proper integration of penalties in the broader social system.

\section{Corporal punishment}

Corporal punishment and penalties involving the loss of civil rights have often been linked to each other and now seem to have been integrated into the justice system at the end of the Middle Ages. The dramatic expansion of the Theatre of Horrors in the cities of northern Europe in the 16th and 17th centuries, and its decline in the 18 th century, has been particularly well researched ${ }^{57}$.

\section{Imprisonment}

As for prison, its origins date back to the 16th century and its integration into state penal systems at the end of the 18 th century has been the object of ground-breaking research ${ }^{58} ; P$. Spierenburg's synthesis explicitly links the evolution of corporal punishment and the emergence of imprisonment. This is a promising avenue because it integrates the analysis of punishment with analysis of societies and underscores the existence of a penal economy that privileges the standardisation of penalties for specific types of social problems. The disappearance of one standard penalty in favour of another illuminates societal mutations ${ }^{59}$.

In a very original manner, crime history integrates new dimensions of research with classical juridical studies. On the one hand, long-term analysis allows the researcher to retrace unexpected correlations (from the judicial pilgrimage to banishment, from expulsion to prison). On the other hand, from the study of punishment as a whole, one can measure interactions between alternative penalties (such as imprisonment instead of banishment). The distinction between judgements and the actual execution of sentences, notably, for example, in the use of pardons, recalls the gap between discourse and practice. Social contextualisation integrates penal rituals with social rituals (such as auto da fé or public executions) that together form the cement of social order.

\section{d) Patterns of Order}

One of the first achievements of crime history was to draw out and analyse the role of repression in conflict resolution. Beyond considering repression as an isolated model, historians are now interested in the role of punishment within the complex, fluctuating and polymorphous processes of social control. The aims of social control and the means employed for its maintenance expose it mainly as a set of cultural conceptions in pre-industrial societies.

57 Spierenburg (1984b); Van Dülmen (1990), Schwerhoff in Blauert, Schwerhoff (1993, p. 158-188).

58 Ignatieff (1978); Melossi, Pavarini (1981); Spierenburg (1984a); Petit (1990); Spierenburg (1991).

59 Rousseaux (1995 a). 


\section{Pacification}

The maintenance of peace was a major concern in medieval societies. Over a period of centuries marked by feudal strife, the church was often the only stable authority and it introduced peace, truces and an entire series of practices aimed at channelling violence ${ }^{60}$.

Cities also sought to free themselves from the brutality and incertitude of feudal forms of justice. Among the bourgeois classes amicitia and coniuratio initiated systems of control among peers in which self-denunciation, negotiation with the injured party, financial and religious sanctions and reconciliation were mutually accepted and valued practices. Princes and sovereigns, for their part, tried to gain a monopoly of keeping the peace notably by ordering their offices to protect the roads and countryside safe. As for rural communities, they developed sophisticated systems of maintaining social cohesion, and calling on the formal justice system to settle disputes was a last resort ${ }^{61}$.

\section{Stigmatisation}

In the framework of these general tendencies, the restoration of order during periods troubled by either religious strife or civil war was frequently accomplished through the stigmatisation of certain social categories or certain types of behaviour. The beginning of the modern period was typical of such an obsessive preoccupation with justice. In order to uphold order against both external and internal threats, heretics, witches, vagrants, suspected dissenters (as in revolutionary France), Jews, free masons, homosexuals and immigrants have all at one time or other become victims of stigmatisation. Also, in this context the activities of less conciliatory justice systems that abused public prosecution, investigatory procedures notorious for their secrecy, the use of torture to obtain confessions, corporal punishment and public executions stand out. At the same time these justice systems were often subject to strong social pressures particularly from victims among the local population, demanding justice.

\section{Forced Labour}

Resocialisation through work was another expedient deployed by justice systems in times of economic crisis ${ }^{62}$. This was particularly apparent perceptible in the context of the 16th century labour crisis, which witnessed the creation of workhouses. During the industrial revolution, this model experienced significant developments: forced labour was integrated with the predominant form of punishment, i.e. imprisonment. From this moment the penal system appear to have focussed on the repression of offences against property, employing more mass prosecutions and the near-monopoly of prison sentences.

\footnotetext{
so Platelle (1971).

6) Lenman, Parker (1980).

62 Diederiks (1992b).
} 
Thirty years of crime and criminal justice history have seen the accumulation of new evidence and interpretation that, in turn, have enriched our knowledge of societies. Furthermore, historiographic debate has constantly brought us beyond the limits encountered in the definition of concepts, the reliability of sources, the methodologies used and the interpretation of quantitative data. Now much better acquainted with patterns of criminals and their crimes, penal history is interested not only in the motives of criminal activity, but also in the social reactions to crime. From analyses based solely on one type of social reaction, i.e. repression, researchers are now discovering and exploring the numerous forms of non-repressive reactions (such as surveillance, pacification and negotiation). Their contributions link the statistics of crime and punishment statistics with larger social structures, which has helped to measure the impact of social relationships and structures in the regulation of conflicts.

Empirical monographs have given birth to a new discipline: the history of criminal justice, in which criminality, criminals, institutions of control and repressive policies are all now indissociable. Let us now look at how the history of pre-industrial societies has influenced the history of criminal justice and how, inversely, the history of criminal justice progressively influences our knowledge of pre-industrial societies.

\section{III - A SOCIAL READING OF CRIMINAL HISTORY}

It is impossible to present all of the contributions made by a discipline that is still in development. This discussion will focus on criminal justice, which lies at the core of the ensemble of agents responsible for conflict regulation. From the 12th to the 19th centuries, the judicial function was prominent in the most significant methods of dealing with «deviant" behaviour. Four factors seem to be particularly linked (though not necessarily in terms of causality) with the development of criminal justice: the construction of territories, forms of power, social relations and mental representations.

\section{a) Social Control, Criminal Justice and Space}

The link between conflict regulation and territory may at first appear odd. However, numerous analyses have demonstrated the central role of the exercise of criminal justice in the definition of autonomously administered territories, as well as the variability of the means of conflict resolution according to the nature of the territorial space in question. In their well-known 1980 article, Lenman and Parker compared two forms of socio-political territories: communities and states ${ }^{63}$.

\section{Rural and Urban Communities: Spaces of Cohesion and Extension}

The development of medieval cities frequently involved a struggle for judicial autonomy, which eventually manifested itself through the participation, if not the seizure, by the bourgeois classes of the implements of regulation. The imposition of fines and judicial pilgrimages, as well as the use of mediators, comprised original forms of conflict regulation that were born in these face-to-face societies. 
Furthermore, judicial space in rural societies was often partitioned. For example, feudal manors, villages and seigniories were more concentrated zones for the expression of power than more expansive territories. Studies carried out on seigniorial justice systems illustrate particular problems arose according to the size of the territory administered and there were particular problems linked to the handling of productive spaces, such as minor infractions on, and the maintenance of, rural and forest property. Practices that originated in communities include 'franches vérités' and pleas that brought whole villages together. Similarly the role played by priests or guilds in urban areas or pastors in consistories of reformed communities, can only be explained by the relatively small size of the communities and confirm the penetration of social ties in justice systems.

\section{Expanding Spaces: States}

The community model of towns and villages fell progressively under the control of a specific form of government, namely, the state. Whether from a centralised point or via the attribution of particular competences, the state successfully imposed its influence over categories of ever-increasing numbers of people. It is difficult to comprehend the success of the state without looking at the impact of its various implements. Royal pardon, inquisitions and patrolling constables provide a few examples of the judicial, institutional or military implements that allowed sovereign powers to accustom people to their role in local life. These means contributed to the progressive creation of a coherent space, much more vast than urban communities or villages alone. However, states should not be equated simply with monarchies or nations. States developed in such a way so as to function in a city, in a region or in a confederation. Nevertheless, the state seems to have followed the example of the monarchy in its development of the repressive justice systems that helped to give birth to greater and greater territorial expanses, as the example of the expansion of the English and French monarchies shows ${ }^{64}$.

\section{b) Social Control, Criminal Justice and Power}

If the regulation of conflicts is often limited to a precise territory, it is always part of a particular configuration of domination. Often, the link between justice and power has been either neglected in juridical studies, or caricatured in politicallyoriented examinations ones. Nonetheless the precise analysis of the real functioning of justice systems reveals the intimate links between power structures and the forms and practices of justice. Whether in the hands of urban oligarchies, rural aristocracies, provincial bourgeois, or officers of the monarchy, all courts favoured specific models when dealing with crime.

Romanised cities, English feudal manors, as well as ecclesiastical immunities have all left behind traces from before the 13 th century of centres where concentrated forms of power persisted ${ }^{65}$. Domain justice seemed to be the most highly developed, or at least the most well-known form of justice. In emerging cities justice systems were organised largely according to bourgeois interests. It is apparent seen that demands for internal security (such as the struggle against clan violence) as well as

64 Strayer (1970); Kaeuper (1988).

w5 Coll. (1995). 
exterior security (protection against feudal powers and mistrust of sovereigns) frequently influenced consular and municipal judges regarding conflicts and their resolutions.

In rural areas local lords commonly put pressure on the peasants until a sovereign succeeded in imposing his forms and ideas of justice upon all his "subjects". The «deterritorialisation» of power brought on by the development of a network of officers of the sovereign disrupted rural areas, which were used to settling their problems at community level under the aegis of «local authorities» such as nobles and local oligarchies.

The steady increase of the sovereign's influence brought about progressive centralisation in matters of justice, as was the case in France, or at the very least the modernisation and rationalisation of its functions, as was the case in England, the Netherlands and Spain. The development of different branches of recourse to justice allowed central powers (sovereigns) or regional powers (parliaments, councils and superior courts) progressively to accustom populations to new forms of state organisms and ways of handling crime. Recent criminal history research also reveals the important synergy between the development and the transformation of judicial regulations and the growing pressure of the state as form of modernised, rationalised and bureaucratised power over local populations ${ }^{66}$.

\section{c) Social Control, Criminal Justice and Social Relations}

Criminal justice and the criminality it records also play a considerable role in social relations, both as indicators of the tensions experienced by people and as vectors of the policies concerning the resolution of major social problems.

\section{Making Communities Peaceful}

The problem for the majority of medieval cities was the regulation of physical violence among their residents. This is why urban authorities became very quickly interested in setting up structures to fight violence. Normative measures not only regulated the right to bear arms, but also forbade them within city limits. Administrative practices from Florence to Utrecht repressed the activities of clan chiefs who were considered violent ${ }^{67}$. Finally, most cities developed specific institutions to combat endemic violence, and such peacemakers operated in north-western cities, often up until the end of the Ancien Régime.

Rural communities were not spared such endemic and often fatal violence. Rural notables were not always able to maintain peace between families whose conflicts might extend to private acts of vengeance. In this context certain sovereigns (in France, Burgundy, Spain and Portugal, for example), intervened to allow offenders to escape from local justice. The extraordinary development of pardons, especially in regards to homicide, reveals how, between the end of the 15th and the 17th centuries, a major local problem could be brought under the control of the sovereign, thus reinforcing the sovereign's prestige, authority and power among his subjects ${ }^{68}$.

66 Hook (1984); Kaeuper (1988); Gauvard (1991).

67 Zorzi (1987); Berents (1976, 1988).

68 Davis (1987). 


\section{Keeping Undesirables Away}

Another problem revealed in the judicial archives is that of the social relationships between stable residents and marginals or transients. The surge of uprooted peasants and jobless workers into the cities weighed heavily on social climates, especially during periods of crisis. At the end of the 15th century, in the middle of the 16th century, during the 17th century wars that devastated central and Northwest Europe, and in even greater numbers in the 18 th century, the presence of vagrants and transients became pressing juridical and political as well as social, problems for cities, monarchs and states ${ }^{69}$. Initially medieval cities employed collective administrative expulsion, with hardly any recognition that this could only be a temporary solution. The recurrence of this phenomenon and the organisation of these excluded masses into groups that were perceived as dangerous quickly showed these measures to be ineffective. During the great economic and social crisis of the 16th century, other solutions emerged that were oriented toward placing inactive people into forced labour. The models of workhouses, galleys and the hôpital général were implemented with varying degrees of success. In a more repressive mode, sentencing to galleys or deportation overseas supplanted these models in the context of the military or demographic expansion of the major colonising nations ${ }^{70}$.

Nevertheless, many jurisdictions remained troubled with these banished and/or vagrant populations, especially in periods of war. In cities, theses populations certainly felt the severity of repressive measures more than inhabitants. More likely to be suspected, they could be tortured largely because of the way they looked, and they often received the most severe forms of corporal punishment. In the countryside, provosts and marshals pursued them relentlessly, arresting them, judging them and executing them, sometimes without any form of trial. The short-sightedness of such social responses, and well illustrated by the branding of vagrants with an hot iron, served only to drive them to even more marginal activities, and contributed to the development of collective criminal activity which, in turn, forstered organised banditry in frontier zones, especially towards the end of the Ancien Régime in both northern and southern Europe ${ }^{71}$.

\section{Containing the Poor}

The problem of the endemic poverty of a very large fringe of residents could be included alongside the problem of vagrancy. In both cities and the countryside, bourgeois-controlled justice systems were obsessed by theft and by the extensive damage caused to woods and fields by the practice of gleaning, carried out by women, children and the elderly ${ }^{72}$. At the end of the 18th century, seigniorial entrepreneurs keen for the rational exploitation of their property reduced community land use rights and criminalised some activities regarded as customs. Justice thus became class justice, a means for the ruling classes to impose their social priorities and economic objectives on the popular classes ${ }^{73}$.

\footnotetext{
69 Schnapper (1991), Beier (1985), Rousseaux (1989).

70 Zysberg (1987), Ekirch (1987).

71 Hobsbawm (1959, 1981); Ortalli (1986); Egmond (1993a).

72 Farge (1974); Corvol (1984); Shoemaker (1991); Root (1994).

73 Thompson (1975).
} 
In this context the emergence of prison as a response to illegality appears clear. The sentence of imprisonment can be included with that of forced labour, the galleys, or deportation, as replacing corporal punishment (notably branding, whipping and expulsion) which was increasingly deemed an inefficient regulator of wandering and impoverished populations. The development of diverse forms of penal incarceration came on very much like a revolution at the end of the Ancien Régime, when bourgeois classes everywhere in Europe were acquiring political power ${ }^{74}$.

\section{d) Social Control, Criminal Justice and Mental Constructions}

The history of crime and criminal justice has also been a history of the cultural representations of crime. Numerous researchers initially believed in the unvarying nature of «crime» and «deviance», beliefs which can still be found a few contemporary studies. The work of historians of criminality has shown the great variability of the concepts of crime and criminals in space as well as in time. Moreover, to paraphrase the psychoanalytic maxim, one could say that «the only crimes are those that we call crimes», i.e., those described as such by regulatory and governing authorities. The «dark figure» is not simply a missing proportion, but it can also include behaviour which, consciously or not, has not been labelled as crime. We still have to define the structures of these collective representations of crime according to the social classes that perpetuate them. Here we come across a problematic where interest in the long term (deep Braudelian time) seeks out a difficult association with the deeply-rooted discourses, images and practices of criminal justice.

\section{Representations of Crime}

Behaviour and different individual actions have been qualified very differently. One level of discourse comes from the sources of law, particularly from judicial norms and doctrines (primary criminalisation). By making homicide the most horrible of crimes against the state, Josse de Damhoudere, a 16th century jurist from Bruges, whose Praxis Criminalium circulated throughout Europe, expressed the «dramatised» conception of an intellectual milieu faced with a crisis in Christianity and identity-sealing social representations. Furthermore, in a period of a crisis of power in place of the cities, this doctrinal discourse betrayed the urban magistrate's shifting preference for monarchical power, shifted over time from divine power. By criminalising theft, homicide and then certain sexual acts, the parliaments of 19th century bourgeois societies, via their environment and their electorate, also revealed the evolution in representations of crime. Similarly, by decriminalising acts committed in privacy, but by criminalising post-war political, commercial or economic acts, are not post-Cold War societies transposing the social disruption between the small group of dominant classes and the mass of people in social stagnation?

A second level of discourse comes from the effectiveness of the prosecution and repression of crimes and their social signification (secondary criminalisation). The focus by a number of jurists on witchcraft from the 15 th to the 17 th centuries prompted a witch hunt: and this seems to have stopped when the chain of denunciations started to reach those upper classes who started the witch hunts in the first place. In certain regions of Spain, the Inquisition was concerned less with pursuing heretics

74 Ignatieff (1978); Petit (1990); Spierenburg (1991). 
than those who committed acts deemed as deviant by local populations ${ }^{75}$. In the 19th century, abortion was frequently prosecuted in bourgeois societies even though it rarely led to actual convictions.

\section{Representations of Repression}

The study of socially valorised forms of repression has fascinated researchers for a long time. The emergence of corporal punishment and its progressive replacement by imprisonment, as well as the role of forced labour have all been the object of much theorising and research. These is the well-known analysis of Michel Foutcault on the re-orientation of the focus of repression from the body to the soul of the delinquent, and else the parallels drawn by Rusche and Kirchheimer between labour crises and the recourse to forced labour and imprisonment, or the use of fines and monetary crises.

Moreover, popular representations of punishment have been particularly studied within the framework of public execution rituals. The rise of the «Theatre of Horrors» in the application of justice in north-western cities goes hand-in-hand with the fascination/repulsion of populations for bloody executions and executioners ${ }^{76}$. What remains to be measured is the significance of the apparently paradoxical evolution in the 18th and 19th centuries from death sentences pronounced in "private» followed by public executions, to death sentences pronounced in public, but executed behind the secrecy of prison walls ${ }^{77}$.

\section{Representations of Procedure}

The social representations of judicial procedures are less well-known. Here we enter the domain of hypothesis, precisely because research on the history of regulation is rare. Western history has presented only typical models of conflict regulation. First there were violent resolutions such as private vengeance, then peacekeeping methods through mutual forgiveness and the re-inforcement of social links between quarrelling parties. These were followed by measures of repression through stigmatisation and exclusion, with focus on specific scapegoats or certain acts (witches, vagabonds, sodomites, businessmen, politicians), and pardon appeared as a sign of favour of a powerful sovereign towards his weaker subjects. However, there were also informal means of conflict regulation. The increasing complexity of social relations seems to correspond to an increasing complexity of the means of conflict regulation and its offshoots.

\section{Representations of Law, Justice and Regulation}

Finally, the entirety of representations of crime from punishment to regulation has contributed to the construction of a social image of law and justice as the modes for regulating the tensions inherent in collective living. The study of these representations is a challenging yet promising domain and combines the analysis of both theoretical and practical texts with figurative representations of justice, based on judicial iconography and archeology. The image of justice, the representations of

\footnotetext{
75 Dedieu (1989).

76 Vanhemelryck (1964-1965); Spierenburg (1984b); Van Dülmen (1990).

77 Evans (1984); Gatrell (1994); Huussen (1994).
} 
judges and the act of judging, models of judicial space (from the church to the court house), and religious references to the act of judgement are so many areas where themes important to anthropologists and law historians encounter the preoccupations of philosophers and sociologists ${ }^{78}$. From a historian's point of view, these studies can only have meaning if closely linked with the analysis of the rituals and practices of justice systems as they are revealed in archives.

\section{IV. - A CRIMINAL READING OF SOCIAL HISTORY}

No study has yet been formulated that could serve as a model for this second approach. Some research in this direction seems to be taking shape in long term analyses. Penal factors play an important role at a number of levels in the construction of societies: in the control of communities, the modernisation of means of government, the construction of states, and in identity formation.

\section{The Civilising of Social Relations}

Influenced by the work of Norbert Elias, researchers have used archives to discover the outlets and the behaviour of populations coping with social tensions. Immediate physical and verbal aggression, as well as the absence of both social stigmatisation and moralisation around certain acts (such as homicide) before the 15th century greatly surprised Western researchers conditioned by a very «civilised» view of social relations. As a result, criminal justice not only seemed to disclose «a world we have lost ${ }^{79}$, but also served as an instrument of moral pacification and progressive acculturation of the popular culture to elite culture, which was mainly religious in the Middle Ages and increasingly more lay and urban from the 15th century ${ }^{80}$.

This pressure of the high on the low is not univocal. Rural populations resisted this intrusion, but also revised it and used it in turn to serve their own interests, as is revealed in studies on the strategies of litigation, which existed not only for elites in higher jurisdictions ${ }^{81}$ but also for local peasants before consistory courts or local magistrates $^{82}$.

\section{The Modernisation of Administration}

Criminality is not the only reality to be found about in judicial archives. Due to the methodological statements of authorities on the selection of cases to be heard in court, the role of judicial administration in social regulation rapidly became of interest to researchers. Sharing many of the concerns of the new history of institutions, historians have revealed the diversity of administrative clusters and the highly organised responses to the problem of crime in Medieval and Early Modern towns and villages in the West. Beyond this diversity, the steady growth of the administrative

78

79

80

81

82

Evans (1982); Jacob (1994); Jacob, Marchal (1992), De Win (1992).

Laslett (1965).

Muchembled (1978).

Johansen, Stevnsborg (1986).

Billacois, Neveux (1990); Bercé, Soman (1995). 
side of justice, best symbolised by the generalisation, on the Continent, of the romano-canonic criminal trial ${ }^{83}$, is indicative of the increasing modernisation of justice systems in Europe and the increasingly monopolistic role of judicial courts in the regulation of conflicts. With modernisation, events were recorded, procedures were rationalised and the exercise of justice was bureaucratised.

Nevertheless, traditional modes of regulation put up a degree of resistance. Autonomous cities held on to their institutions until their full integration into nation states. Local practices survived in communities and recourse to official justice systems is but one indication that local social conflict resolution efforts had failed to maintain order. Nevertheless, the ponderous practices of administrations were settling in. Throughout the diversity of traditions (English or Continental, northern or Mediterranean), judicial administrations tended to be organised and structured into a hierarchy following the monarchical model. The political revolutions that put an end to the Ancien Régime progressively introduced the administrative branches that would be responsible for different social functions: surveillance and prosecution (police), judgement (justice) and punishment (penitential administration).

\section{The Formation of the State}

Modernisation is part of and contributes to the process of the formation of the state as a particular system of societal control and administration, structurally independent of the people or their relations in the dominant positions. The genesis of the modern state is an area of research that has had enormous success in the past few years in Europe ${ }^{84}$. Nevertheless, much research on the history of crime has revealed that the role of justice, and in particular criminal justice, has hardly been integrated into different studies of the origins of the modern state. One of the seminars in which Herman Diederiks participated in the last few years tried to develop this aspect on the basis of empirical research, regional analyses and further theoretical readings ${ }^{85}$. It seems that what is at stake in the stronghold of institutional and judicial functions is mainly symbolic, territorial and political. It is symbolic in that the control of the power to punish or pardon is more than a means for a local or central power figure to profit from economic surplus. It serves to make the population aware of the existence of a power far superior to local powers, i.e. the one who holds claim to sovereignty. It is territorial because the command of the systems of social control (justice, police) is a means of extending the implantation of the state to frontier or rebellious zones. It is political because, in the end, alongside the control of taxes and war, control of the justice system constitutes a monopoly over legitimate violence which in turn legitimises the state, the successor to the city and the monarch as the sole recourse to social peace.

\section{The Constitution of Social Identities}

A last domain to which crime and criminal justice history can make significant contributions is that of the formation of identities and collective representations. Who defines crime? Who is defined as a criminal? What are the links between offi-

\footnotetext{
83 Langbein $(1974,1977)$.

84 Genet (1990).

85 Rousseaux, Lévy (1997).
} 
cial definitions and the representations of social groups or classes of victims, witnesses or offenders involved in acts committed? How do the punishment, the crime and modes of regulation contribute to the construction and the deconstruction of identities, collective psyches and social mythologies?

\section{CRIME AND JUSTICE: ELEMENTS OF SOCIAL HISTORY}

Thirty years of the history of crime and criminality, which have been encompassed by thirty years of the research of Herman Diederiks, have resulted in the integration into social history of a research domain that has for much too long been limited to the work of legal historians or to anecdotal approaches. Through its diversity and complementarity, the work of crime historians without any doubt offers important material for the study of social regulation. Nevertheless, the study of formal justice as both an indicator and a producer of mechanisms of exclusion and social integration within a vast ensemble of functional social procedures and processes is a construction site on which building has to continue alongside political, economic, juridical and cultural histories.

Until now, the construction site upon which crime and criminal justice history has been built has empirically innovative by combining quantitative and qualitative approaches, macro- and micro-social approaches, and juridical and anthropological approaches. It is also a theoretically important site in the way that it gives shape to concepts dictated by social history. Finally, it is a multidisciplinary site in its privileging of true dialogue between historians and contemporary specialists of crime (jurists, criminologists, sociologists, political scientists); it can contribute to a better integration of sociological literature in long-term research, and create more explicit links between the past and the present, and between the social sciences and history ${ }^{86}$.

Translated by Kevin Dwyer

\section{BIBUOGRAPHY}

Agulhon, M., La République au village: les populations du Var de la Révolution à la $2^{e}$ République, Paris, 1970a.

Agulhon, M., La vie sociale en Provence intérieure au lendemain de la Révolution, Paris, $1970 \mathrm{~b}$.

Ankarloo, B., Henningsen, G., (eds.), Early Modern European Witchcraft. Centres and Peripheries, Oxford, 1990.

Aubusson de Cavarlay, B., Can Criminal Statistics Still Be of Scientific Use? The French Criminal Justice System, 1831-1980, Historical Methods, 1993, 26-2, p. 69-84.

Aubusson de Cavarlay, B., Baré V., Dupont-Bouchat, M.S., Rousseaux, X., Teirlynck, A.M., Vael, C., La pratique des juridictions criminelles du département de Sambre-et-Meuse à l'époque française (1796-1815): une analyse quantitative, in Rousseaux, X., DupontBouchat, M.S., Vael, C., (eds.), Révolutions et Justice pénale en Europe (1780-1830). Modèles français et traditions nationales / Revolution and Criminal Justice in Europe, 1780-1830 French Models and National Traditions, Paris, (forthcoming). 
Bader, K., Aufgaben, Methoden und Grenzen einer historischen Kriminologie, Schweizerische Zeitschrift für Strafrecht, 1956, 71, p. 17-31.

Bailey, V., Reato, giustizia penale e autorità in Inghilterra. Un decennio di studi storici, 19691979, Quaderni Storici, 1979, 44, p. 581-603.

Bailey, V., Bibliographical essay: crime, criminal justice and authority in England, Bulletin of the Society for the Study of Labour History, 1980, 40, p. 36-46.

Battenberg, F., Ranieri, F. (eds.), Geschichte der Zentraljustiz in Mitteleuropa, WeimarCologne-Wien, 1994.

Beattie, J.-M., Crime and the Courts in England, 1660-1800, Oxford, 1986.

Beier, A.L., Masterless Men; The Vagrancy Problem in England 1560-1640, London, 1985.

Bercé, Y.M., Castan, Y. (eds.), Les archives du délit, empreintes de société, Toulouse, 1990.

Bercé, Y.-M., Soman, A., La justice royale et le parlement de Paris (XIV ${ }^{e}-X V^{e}$ siècle), Bibliothèque de l'Ecole des Chartes, 1995, 153, p. 251-437.

Berents, D.A., Misdaad in de middeleeuwen. Een onderzoek naar de criminaliteit in het laatmiddeleeuwse Utrecht, Utrecht, 1976.

Berents, D.A., Het werk van de vos. Samenleving en criminaliteit in de late middeleeuwen, Zutphen, 1988.

Billacois, F., Pour une enquête sur la criminalité dans la France d'Ancien Régime, Annales E.S.C., 1967, 22, p. 340-349.

Billacois, F., Criminalistes, pénalistes et historiens, Annales E.S.C., 1969, 24, p. 911-914.

Billacois, F., Neveux H. (eds.), Porter plainte. Stratégies villageoises et justice en Ile-deFrance, Droit et Culture, 1990, 19, p. 5-148.

Blasius, D., Eigentum und Strafe. Probleme der preussischen Kriminalitäts- und Strafrechtsentwicklung im Vormärz, Historische Zeitschrift, 1975, 220, p. 79-129.

Blasius, D., Kriminalität und Alltag. Zur Konfliktgeschichte des Alltagslebens im 19. Jahrhundert, Göttingen, 1978.

Blasius D., Geschichte der politischen Kriminalität in Deutschland 1800-1980. Eine Studie zu Justiz und Staatsbverbrechen, Frankfurt/Main, 1983.

Blauert A., Schwerhoff G., (eds.), Mit den Waffen der Justiz. Zur Kriminalitätsgeschichte des späten Mittelalters und der Frühen Neuzeit, Frankfurt/Main, 1993.

Blok, A., The Mafia of a Sicilian Village 1860-1960. A Study of Violent Peasant Entrepreneurs, Oxford, 1974.

Blok, A., The Bokkerijders. Roversbenden en geheime genootschappen in de Landen van Overmaas, 1730-1774, Amsterdam, 1991.

Bois, P., Paysans de l'Ouest. Des structures économiques et sociales aux options politiques depuis l'époque révolutionnaire, Paris-The Hague, 1960.

Brackett, J., Criminal Justice in Late Renaissance Florence, 1537-1609, Cambridge, 1992.

Braudel, F., La Méditerranée et le monde méditerranéen à l'époque de Philippe II, Paris, 1949 (1st ed.).

Castan, N., Justice et répression en Languedoc à l'époque des Lumières, Paris, 1980a.

Castan, N., Les criminels de Languedoc, 1750-1790, Toulouse, $1980 \mathrm{~b}$.

Castan, N., Assesment of the Contribution of Historical Research to the Understanding of Crime and Criminal Justice, in Council of Europe, Historical research on crime and criminal research. Reports presented to the Sixth Criminological colloquium, Strasbourg, 1984.

Castan, Y., Honnêteté et relations sociales en Languedoc, 1715-1780, Paris, 1974.

Castan, Y., Magie et sorcellerie à l'époque moderne, Paris, 1979.

Chaunu, H., Chaunu, P., Séville et l'Atlantique (1504-1650), 12 vol., Paris, 1955-1960. 
Chaunu, P., Déviance et intégration sociale: la longue durée, Marginalité, Déviance et Pauvreté en France, XIV-XIX ${ }^{e}$ s. Cahiers des Annales de Normandie, 1981, 13, p. 5-16.

Cobb, R., The Police and the People: French Popular Protest 1789-1820, Oxford, 1970.

Cohen, S., Scull A., Social Control and the State. Historical and Comparative Essays, Oxford, 1986 (2nd ed.).

Coll., Twelve years of research on the history of crime and criminal justice (1978/1990), I.A.H.C.C.J. Bulletin, 1991,14.

Coll., La giustizia nell'alto medioevo (secoli $V^{0}$-VII $)$, 2 vol., Spoleto, 1995.

Corbin, A., Le village des cannibales, Paris, 1990.

Corvol, A., L'homme et l'arbre sous l'Ancien Régime, Paris, 1984.

Coutau-Bégarie, H., Le phénomène «Nouvelle Histoire». Stratégie et idéologie des nouveaux historiens, Paris, 1989 (2nd ed.).

Criminal Justice History, An International Annual, 1980, I - 1996, XIV.

Curtis, T., Explaining Crime in Early Modern England, Criminal Justice History, 1980, 2, p. 117-137.

de la Croix, D., Rousseaux, X., Urbain, J.P., To Fine or To Punish in the Late Middle Ages. A Time Series Analysis of Justice Administration in Nivelles, 1424-1536, Applied Economics, 1996, 28, p.1213-1224.

Davis, N.Z., Fiction in the Archives: Pardon Tales and their Tellers in Sixteenth Century France, Stanford, 1987.

Dedieu, J.P., L'Administration de la foi: l'inquisition de Tolède, XVI'-XVIII siècles, Madrid, 1989.

De Win P., (ed.), Rechtsarcheologie en Rechticonografie. Een kennismaking/Rechtsarchäologie und Rechtsikonographie. Eine Annäherung, Brussels, 1992.

Deyon, $\mathrm{P}$., Le temps des prisons, essai sur l'histoire de la délinquance et les origines du système pénitentiaire, Lille, 1975.

Diederiks, H., Strafrecht en criminaliteit in de $18 \mathrm{e}$ eeuw, Holland Regionaal-historisch tijdschrift, 1976, 8, 3.

Diederiks, H., Patterns of Criminality and Law Enforcement during the Ancien Regime; the Dutch Case, Criminal Justice History, 1980, 1, p. 157-174.

Diederiks, H., «Punishment during the Ancien Regime: the case of the 18th century Dutch Republic", in Knafla, L.A.(ed.), Crime and Criminal Justice in Europe and Canada, Waterloo (Ont.), 1981, p. 273-296.

Diederiks, H. (ed.), Different Systems of Criminal Law: Confrontation or Assimilation, I.A.H.C.C.J.-Newsletter, 1985, 9, p. 35-82.

Diederiks, H., In een land van justitie: criminaliteit van vrouwen, soldaten en ambtenaren in de achttiende-eeuwse Republiek, Hilversum, 1992a.

Diederiks, H., Forced Labour in the Penal System, in the Poor Relief System and in the Dutch Colonies Since the 18th Century, I.A.H.C.C.J.-Bulletin, 1992b, 16, p. 34-40.

Diederiks, H., De sociale geschiedenis van criminaliteit, strafrecht en strafrechtspraktijk, Panopticon, 1993, 14, 6, p.505-515.

Diederiks, H., Norbert Elias and the Development of Criminality: An Introduction, I.A.H.C.C.J.-Bulletin, 1995, 20, p.15-16.

Diederiks, H., Faber, S., Misdaad en straf: verleden tijd?, Tijdschrift voor Criminologie, 1978, p. 105-112.

Diederiks, H., Huussen, A.-H., Crime and Punishment in the Dutch Republic (XVIII-XIX centuries) in La Peine. Punishment, 3d part: Europe Since the 18th Century, Brussels, 1989, p. 133-159. 
Diederiks, H., Roodenburg H.W., (eds.), Misdaad, zoen en straf: aspekten van de middeleeuwse strafrechtsgeschiedenis in de Nederlanden, Hilversum, 1991.

Dufresne, J.L., Les comportements' amoureux d'après le registre de l'officialité de Cerisy, Bulletin philologique et historique du Comité des travaux historiques et scientifiques, 1976, p. 131-156.

Dupont-Bouchat, M.S., (ed.), La sorcellerie dans les Pays-Bas d'Ancien Régime. Aspects juridiques, institutionnels et sociaux-De hekserij in de Nederlanden onder het Ancien Régime. Juridische, institutionele en sociale aspecten, Kortrijk-Heule, 1987.

Dupont-Bouchat M.S., Rousseaux, X., Le prix du sang. Sang et justice du XIV au XVIII ${ }^{e}$ s., Mentalités, 1989, 1, p. 43-72.

Egmond, F., Banditisme in de Franse Tijd. Profiel van de Grote Nederlandse Bende, 17901799, s.1., 1986.

Egmond, F., Underworlds. Organized Crime in the Netherlands, 1650-1800, Cambridge, 1993a.

Egmond, F., Children in Court: Children and Criminal Justice in the Dutch Republic, Social \& Legal Studies, 1993 b, 2, p. 73-90.

Eibach, J., Neue Historische Literatur. Kriminalitätsgeschichte zwischen Sozialgeschichte und Historischer Kulturforschung, Historische Zeitschrift, 1996, 263, p. 681-715.

Ekirch, A.R., Bound for America. The Transportation of British Convicts to the Colonies, 1718-1775, Oxford, 1987.

Elias, N., Über den Prozess der Zivilisation: soziogenetische und psychogenetische Untersuchungen, 2 vol., Bern, 1969, 2nd ed.

Elton, G., Introduction: Crime and the Historian, in Cockbum, J.S.(ed.), Crime in England, 1550-1800, London, 1977, p. 1-14.

Emsley, C., Crime and Society in England 1750-1900, London-New-York, 1987.

Emsley, C., Knafla, L., (eds.), Crime History and Histories of Crime. Studies in the Historiography of Crime and Criminal Justice in Modern History, Westport (Conn.), 1996.

Evans R., The Fabrication of Virtue. English Prison Architecture, 1750-1840, Cambridge, 1982.

Evans, R.J., Öffentlichkeit und Autorität. Zur Geschichte der Hinrichtungen in Deutschland vom Allgemeinen Landrecht bis zum Dritten Reich, in Reiff, H., (ed.), Räuber, Volk und Obrigkeit. Studien zur Geschichte der Kriminalität in Deutschland seit dem 18. Jahrhundert, Frankfurt am M., 1984, p. 185-258.

Evans, R.J., (ed.), The German Underworld. Deviants and Outcasts in German History, London/New York, 1988.

Faber S., Monumenta of chips? Strafrechtshistorisch onderzoek en het uitgeven van bronnen, Verslagen en mededelingen van de Stichting tot uitgaaf der bronnen van het oudvaderlandse recht, 1980, 2, p. 101-106.

Faber, S., Strafrechtspleging en criminaliteit te Amsterdam (1680-1811). De nieuwe menslievenheid, Arnhem, 1983.

Faber, S. et al. (eds.), Tien jaar werkgroep strafrechtsgeschiedenis, 1973-1983, LeidenAmsterdam, 1983.

Farge, A., Le vol d'aliments à Paris au XVIII' siècle, Paris, 1974.

Farge, A., La vie fragile: violence, pouvoirs et solidarités à Paris au XVIII siècle, Paris, 1986.

Foucault, M., Discipline and Punish: the Birth of the Prison, Harmondsworth, 1979. [English translation of the original version Surveiller et punir. Naissance de la prison, Paris, 1975.] 
Franke, H., The Rise and Decline of Solitary Confinement: Socio-Historical Explanations of Long-Term Penal Changes, British Journal of Criminology, 1992, 32-2, p. 125-143.

Garnot, B., Une illusion historiographique: justice et criminalité au XVII' ${ }^{e}$ siècle, Revue Historique, 1989,570 , p. 362-379.

Gamot, B. (ed.), Histoire et Criminalité de l'Antiquité au XXe siècle. Nouvelles approches, Dijon, 1992.

Garnot, B., (ed.), Ordre moral et délinquance de l'Antiquité au XX siècle, Dijon, 1994.

Garnot, B. (ed.), L'infrajudiciaire du Moyen Age à l'époque contemporaine, Dijon, 1996.

Gaskill, M, Meldrum T., «Crime, the Law, and the State»: University of Essex/Istituto Italiano per gli Studi Filosofici, Naples, Comparative History Summer School, 6-10 July 1992, Social History, 1993, 18-1, p. 87-91.

Gatrell, V.-A.-C., Lenman, B., Parker, G., (eds.), Crime and the Law. The Social History of Crime in Western Europe since 1500, London, 1980.

Gatrell, V.-A.-C., The Hanging Tree Execution and the English People, 1770-1868, Oxford, 1994.

Gauvard, C., «De grace especial». Crime, État et Société en France à la fin du Moyen Age, 2 vols., Paris, 1991.

Gauvard, C., Violence citadine et réseaux de solidarité. L'exemple français aux XIV et XV siècles, Annales E.S.C., 1993, p. 1113-1126.

Gégot, J.C., Storia della criminalità: le ricerche in Francia, Quademi Storici, 1981, 46, p. 192-211.

Genet, J.P., L'État moderne: genèse. Bilans et perspectives, Paris, 1990.

Geremek, B., Criminalité, vagabondage, paupérisme: La marginalité à l'aube des temps modernes, Revue d'Histoire Moderne et Contemporaine, 1974, 21, p. 337-375.

Geremek, B., Inutiles au monde. Truands et misérables dans l'Europe moderne (1350-1600), Paris, 1980.

Geremek, B., La potence ou la pitié. L'Europe et les pauvres du Moyen Age à nos jours, Paris, 1987.

Ginzburg, C., The Cheese and the Worms: The Cosmos of a Sixteenth-Century Miller, London, 1980.

Ginzburg, C., The Night Battles: Witchcraft and Agrarian Cults in the Sixteenth and Seventeenth Centuries, Baltimore \& London, 1983 [Orig. ed.: I Benandanti: Stregoneria e culti agrari tra Cinquecento e Seicento, Turin, 1973, 2nd ed.].

Gonthier, N., Cris de haine et rites d'unité. La violence dans les villes (XIII'-XVI' siècles), Turnhout, 1992.

Goubert, P., Beauvais et le Beauvaisis de 1600 à 1730, contribution à l'histoire sociale de la France du XVII siècle, Paris, 1960.

Hanawalt, B., Observe of the Civilizing Process in Medieval England, IAHCCJ Bulletin, 1995, 20, p. 49-60.

Hay, D., Crime and Justice in Eighteenth- and Nineteenth-Century England, Crime \& Justice. An Annual Review of Research, 1980, 2, p. 45-84.

Hay, D., The criminal prosecution in England and its historians, The Modern Law Review, 1984, 47, 1-29.

Hobsbawm, E.J., Primitive Rebels, Manchester, 1959.

Hobsbawm, E.J., Bandits, New York, 1981 (Rev. edn.).

Hoffer, P.C., Counting crime in premodern England and America. A review essay, Historical Methods, 1981, 14-4, p. 187-193. 
Hook, J.A, Justice, Authority and the Creation of the Ancien Régime in Italy, Transactions of the Royal Historical Society, 1984, 34, p. 71-89.

Hufton, O., Crime in Pre-Industrial Europe, I.A.H.C.C.J.-Newsletter, 1981, 4, p. 8-35.

Huussen, A.-H., Strafrechtspraktijk en criminaliteit in het verleden, een tekening in het grensgebied tussen realistische en sociale geschiedenis, Groniek, 1976, p. 23-29.

Huussen A.H., Veroordeeld in Friesland. Criminaliteitsbestrijding in de eeuw der Verlichting, Leeuwarden, 1994.

I.A.H.C.C.J., Newsletter, 1979, 1 -1990, 13; then I.A.H.C.C.J.-Bulletin, 1991, $14-1997,21$.

Ignatieff, M., A Just Measure of Pain. The Penitentiary in the Industrial Revolution (17501850), New York, 1978.

Innes, J., Styles, J., The Crime Wave: Recent Writing on Crime and Criminal Justice in Eighteenth-Century England, Journal of British Studies, 1986, 25, 4, p. 380-435.

Jacob, R., Images de la justice. Essai sur l'iconographie judiciaire du Moyen Age à l'âge classique, Paris, 1994.

Jacob, R., Marchal, N., Jalons pour une histoire de l'architecture judiciaire, in La justice en ses Temples. Regards sur l'architecture judiciaire en France, Paris-Poitiers, 1992, p. 2368.

Johansen, J.C.V., Stevnsborg, H., Hasard ou myopie? Réflexions autour de deux théories de l'histoire du droit, Annales E.S.C., 1986, 41, 3, p. 601-624.

Johnson, E.A. (ed.), Quantification and Criminal Justice History in International Perspective, Historical Social Research/Historische Sozialforschung, Special Issue, 1990, 15, 4.

Kaeuper, R.W., War, Justice and Public Order. England and France in the Later Middle Ages, Oxford, 1988.

Killias, M., Rehbinder, M. (eds.), Rechtsgeschichte und Rechtssociologie, Berlin, 1985.

Kitsuse, J.I., Cicourel, A.V., A Note on the Use of Official Statistics, Social Problems, 1963, 12, p. $131-139$.

Knafla, L. (ed.), Crime and Criminal Justice in Europe and Canada, Waterloo (Ont.) 1981.

Knafla, L.A., Structure, Conjuncture, and Event in the Historiography of Modern Criminal Justice History, in Emsley, Knafla, 1996, p. 33-44.

Lagrange, H., La civilité à l'épreuve. Crime et sentiment d'insécurité, Paris, 1995.

Langbein, J., Prosecuting Crime in the Renaissance. England, Germany, France, Cambridge (Mass.), 1974.

Langbein, J. Torture and the Law of Proof. Europe and England in the Ancien Régime, Chicago, 1977.

Lascoumes, P., Zander, H., Marx: du «vol de bois» à la critique du droit. Karl Marx à la "Gazette Rhénane", naissance d'une méthode, Paris, 1984.

Laslett, P., The World we Have Lost, London, 1965.

Lenman, B., Parker, G., The State, the Community and the Criminal Law in Early Modern Europe, in Gatrell, V.A.C., Lenman, B., Parker, G., (eds.), Crime and the Law: The Social History of Crime in Western Europe since 1500, London, 1980, p. 11-48.

Le Roy Ladurie, E., Les Paysans de Languedoc, Paris, 1966.

Le Roy Ladurie E., La décroissance du crime au XVIII ${ }^{e}$ siècle, bilan d'historiens, Contrepoint, 1973, 9, p. 227-233.

Le Roy Ladurie, E., Montaillou village occitan, Paris, 1975 [Montaillou: Cathars and Catholics in a French Village 1294-1324, London, 1978.].

Lepetit, B., (ed.), Les formes de l'expérience. Une autre histoire sociale, Paris, 1995.

Lévy, R., Robert, Ph., Le sociologue et l'histoire pénale, Annales E.S.C., 1984, 39, 2, p. 400422. 
Lévy, R., Rousseaux, X., États, justice pénale et histoire: bilan et perspectives, Droit et Société, 1992, 20-21, p. 249-279.

Macfarlane, A., Witchcraft in Tudor and Stuart England: A Regional and Comparative Study, London, 1970.

Mc Mullan, J.L., Crime, Law and Order in Early Modem England, British Journal of Criminology, 1987, 27, 3, p. 252-274.

Meer (van der) T., «De wesentlijcke sonde van sodomie en andere vuyligheden». Sodomietenvervolgingen in Amsterdam, 1730-1811, Amsterdam, 1984.

Melossi, D., Paravini, M., The Prison and the Factory: The Origins of the Penitentiary System, London, 1981.

Mollat, M., (ed.), Études sur l'histoire de la pauvreté, 2 vol., Paris, 1974.

Monkonnen, E., Systematic Criminal Justice History: some Suggestions, Journal of Interdisciplinary History, 1979, 9, p. 451-464.

Monkonnen, E., The History of Crime and Criminal Justice after Twenty-Five Years, Criminal Justice History, 1984, 5, p. 161-169.

Monter, W.,The new Social History and the Spanish Inquisition, Journal of Social History, 1984,17 , p. $705-713$.

Moore, R.I, The Formation of a Prosecuting Society. Power and Deviance in Western Europe (950-1250), Oxford, 1987.

Moorman van Kappen, O., Die sogenannte neue Forschungrichtung zur Kriminalitätsgeschichte in den Niederlanden und Belgien, Zeitschrift für neuere Rechtsgeschichte, 1984, 6, p. 153-162.

Mooser, J. «Furcht bewahrt das Holz». Holzdiebstahl und sozialer Konflikt in der ländlichen Gesellschaft 1800-1850 an westfälischen Beispielen, in Reif, H., (ed.), Studien zur Geschichte der Kriminalität in Deutschland seit dem 18. Jahrundert, Frankfurt am Main, 1984, p. 43-99.

Muchembled, R., Culture populaire et culture des élites dans la France moderne (XV-XVIII siècles), Paris, 1978.

Muchembled, R., Anthropologie de la violence dans la France moderne (XV'-XVIII siècles), Revue de Synthèse, 1987, 108, p. 31-55.

Muchembled, R., L'invention de l'homme moderne. Sensibilités, maurs et comportements collectifs sous l'Ancien Régime, Paris, 1988.

Muchembled, R., Le temps des supplices. De l'obéissance sous les Rois absolus. XV'-XVIII siècles, Paris, 1992.

Muchembled, R., (ed.), Magie et sorcellerie en Europe, Paris, 1994.

Nye, R.A., Crime in Modern Societies: Some Research Strategies for Historians, Journal of Interdisciplinary History, 1978, 11, p. 491-507.

O' Brien, P., Crime and Punishment as Historical Problem, Journal of Social History, 1978, 11, p. 508-520.

Ortalli, G., (ed.), Bande armate, banditi, banditismo e repressione di giustizia negli stati europei di antico regime, Rome, 1986.

Otis, L.L., Prostitution in Medieval Society. The History of an Urbain Institution in Languedoc, Chicago/London, 1985.

Parker, G., Crime and the Early Modern Historian. A Review Article, Tijdschrift voor Geschiedenis, 1981, 94, p. 595-601.

Petit, J., Ces peines obscures. La prison pénale en France 1780-1875, Paris, 1990.

Pihlajamäky, H., (ed.), Theatres of Power. Social Control and Criminality in Historical Perspective, s.l., 1991. 
Platelle, H., La violence et ses remèdes en Flandre au XI ${ }^{c}$ siècle, Sacris Erudiri, 1971, 20, p. $101-173$.

Post, J.B., Crime in Later Medieval England: some Historiographical Limitations, Continuity and Change, 1987, 2, 2, p. 211-224.

Powell, E., Social Research and the Use of Medieval Criminal Records, Michigan Law Review, 1981, 79, p. 967-978.

Pugh, R.B., Some Reflections on a Medieval Criminologist, Proceedings of the British Academy, 1973, 59, p. 83-104.

Ramsey, M.-N., L'évolution du concept de crime. L'étude d'un toumant: l'Angleterre de la fin du XVIII siècle, Déviance et Société, 1979, 3, 2, p. 131-147.

Robert, Ph., Emsley, C., (eds.), Geschichte und Sociologie des Verbrechens. History and Sociology of Crime. Histoire et sociologie du crime, Pfaffenweiler, 1991.

Robert, Ph., Lévy, R., Histoire et question pénale, Revue d'Histoire Moderne et Contemporaine, 1985, 27, p. 481-526.

Robert, Ph., Lévy, R., A Changing Penal Economy in French Society: In Search of a Historical View, Historical Social Research, 1986, 37, p. 17-39

Romer, H., Historische Kriminologie - zum Forschungsstand in der deutschsprachigen Literatur der letzte zwanzig Jahre, Zeitschrift für Neuere Rechtsgeschichte, 1992, 14, p. 227-242.

Root, H., La construction de l'État moderne en Europe. La France et l'Angleterre, Paris, 1994.

Rossiaud, J., La prostitution médiévale, Paris, 1988.

Roth, R., Histoire pénale, histoire sociale: même débat?, Déviance et Sociêté, 1981, 5, p. 187. 203.

Roth, R., Evaluation of the contribution of historical research to crime policy and the forecasting of trends in crime policy, taking into account the changes in the social and economic context, in Council of Europe, Historical research on crime and criminal research. Reports presented to the Sixth Criminological colloquium, Strasbourg, 1984.

Rousseaux, X., L'incrimination du vagabondage en Brabant (14 $14^{\mathrm{e}}-18^{\mathrm{e}}$ siècles). Langages du droit et réalités de la pratique, in van Dievoet, G., Godding, P, van den Auweele, D., (eds.), Langage et droit à travers l'histoire. Réalités et fictions, Louvain-Paris, 1989, p.147-183.

Rousseaux, X., Criminality and Criminal Justice In Europe 1250-1850. A Select Bibliography, Criminal Justice History, An Intemational Annual, 1993, 14, p. 159-181.

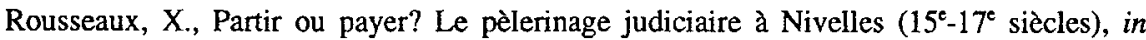
Dauchy, S., Sueur, P., La Route. Actes des Journées internationales tenues à Enghien-lesBains du 13 au 15 mai 1994, Lille, 1995a, p. 105-140.

Rousseaux, X, La répression de l'homicide en Europe occidentale (Moyen Age et temps modernes), Genèses, 1995b, 19, p. 122-147.

Rousseaux, X., From Medieval Cities to National States. Historiography on Crime and Criminal Justice In Europe 1350-1850 in Europe, in Emsley C., Knafla L., 1996, p. 3-32.

Rousseaux, X., Emsley, C., Châtiment, justice, prison, à travers l'histoire/Punishments, Penalties and Prisons in Historical Perspective, in XVIIF Congrès International des Sciences Historiques/18th International Congress of Historical Sciences, Actes / Proceedings; Montréal, 1995, p. 335-353.

Rousseaux, X., Lévy, R. (eds.), Le pénal dans tous ses États. Justice, États et société en Europe (XII'-XXe siècles) et le pénal, Bruxelles, 1997, forthcoming.

Rusche, G., Kirchheimer, O., Punishment and Social Structure, New-York, 1939. (reed. New York, 1968) [German translation: Sozialstruktur und Strafuollzug, Frankfurt am Main, 2d 
ed.1981; Italian transl. Pena e Struttura sociale, Bologne, 1978; French transl.: Peine et structure sociale. Histoire et théorie critique du régime pénal, Paris, 1994].

Sack, F., Kriminalität, Gesellschaft und Geschichte: Berührungsängste der deutschen Kriminologie, Kriminologisches Journal, 1987, 19, 4, p. 241-268.

Saurer, E., Dieci anni di studi austriaci di storia della criminalità e del diritto penale, Quaderni Storici, 1982, 49, p. 217-225.

Sbriccoli, M., Fonti giudiziarie e fonti giuridiche. Riflessioni sulla fase attuale degli studi di storia del crimine et della giustizia criminale, Studi Storici, 1988, 2, p. 491-501.

Schnapper, B., Voies nouvelles en histoire du droit. La justice, la famille, la répression pénale (XVR'-XXe siècles), Poitiers, 1991.

Schwerhoff, G., Devianz in der alteuropäischen gesellschaft. Umrisse einer historischen Kriminalitätsforschung, Zeitschrift für historische Forschung, 1992, 19, 4, p. 385-414.

Sharpe, J.A., Report on the conference organized by the Dutch Group for the Study of the History of Crime and the Criminal Law, 16-18 May 1977, Social History, 1978, 3, 1, p. 83-87.

Sharpe, J.A., The History of Crime in Late Medieval and Early Modern England: a Review of the Field, Social History, 1982, 7-2, p. 187-203.

Sharpe, J.A., Crime in Early Modern England 1550-1750, London-New-York, 1984.

Sharpe, J.A, The History of Crime in England, c. 1300-1914. An Overview of Recent Publications, British Journal of Criminology, 1988, 28, 2, p. 124-137.

Sharpe J.A., Judicial Punishment in England, London-Boston, 1990.

Shoemaker, R., Prosecution and punishment: Ppetty Crime and the Law in London and Rural Middelsex, c. 1660-1725, Cambridge, 1991.

Smaus, G., Kriminologie und geschichte. Eine Einführung, Kriminologisches Journal, 1987, 19, 1, p. 3-15.

Söderberg, J., Civilisering, marknad och vald $i$ Sverige 1750-1870; En regional analys, Stockholm, 1993. [The Civilizing Process, Markets, and Violence in Sweden 1750-1870: a Regional Analysis]

Soman, A., Deviance and Criminal Justice in Western Europe, 1300-1800: an Essay in Structure, Criminal Justice History, 1980, 1, p. 1-28.

Soman, A., Sorcellerie et justice criminelle: le Parlement de Paris (16 $16^{e}$ siècles), Aldershot, 1992.

Spierenburg, P., Criminele geschiedenis. Een literatuuroverzicht, Tijdschrift voor Sociale Geschiedenis, 1981, 23, p. 251-264.

Spierenburg, P., (ed.), The Emergence of Carceral Institutions: Prisons, Galleys and Lunatic asylums 1550-1900, Rotterdam, 1984a.

Spierenburg, P., The Spectacle of Suffering. Executions and the Evolution of Repression: from a Preindustrial Metropolis to the European Experience, Cambridge, 1984b.

Spierenburg, P., Evaluation of the Conditions and Main Problems Relating to the Contribution of Historical Research to the Understanding of Crime and Criminal Justice- Report, in Council of Europe, Historical Research on Crime and Criminal Research. Reports presented to the Sixth Criminological colloquium, Strasbourg, 1985, p. 49-95.

Spierenburg, P., Deviance and Repression in the Netherlands. Historical Evidence and Contemporary Problems, Historical Social Research, 1986, 37, p. 4-16.

Spierenburg, P., The Prison Experience. Disciplinary Institutions and their Inmates in Early Modern Europe, Cambridge, 1991.

Spierenburg, P., Elias and the History of Crime and Criminal Justice: a Brief Evaluation, I.A.H.C.C.J.-Bulletin, 1995, 20, p. 17-30. 
Strayer, J.R., On the Medieval Origins of the Modern State, Princeton, 1970.

Sundin, J., Current Trends in the History of Crime and Criminal Justice: Some Conclusions, with Special Reference to the Swedish Experience, Historical Social Research, 1990, 56, p. 184-196.

Thome, H., Gesellschafliche Modernisierung und Kriminalität. Zum Stand der sozialhistorischen Kriminalitätsforschung, Zeitschrift für Soziologie, 1992, 21, p. 212-228.

Thompson, E.P., The Making of the English Working-Class, London,1963.

Thompson, E.P., Whigs and Hunters: the Origins of the Black Act, London, 1975.

Van der Wee, H., The Growth of the Antwerp Market and the European Economy (Fourteenth-Sixteenth Centuries), 3 vols., Paris-Louvain-The Hague, 1963.

Van Diilmen, R., Theatre of Horror. Crime and Punishment in Early Modern Germany, Cambridge, 1990. [Translated from: Theater des Schreckens. Gerichtspraxis und Strafrituale der frühen Neuzeit, Munich, 1985.].

Van Dülmen, R., Verbrechen, Strafen und soziale Kontrolle, Frankfurt am Main, 1990.

Vanhemelryck, F., De beul van Brussel en zijn werk, (XIV ${ }^{\mathrm{c}}-\mathrm{XIX}^{\mathrm{c}}$ eeuw), in Bijdragen en Mededelingen betreffenden de Geschiedenis der Nederlanden, 1964-1965, 19, p. 181216.

Vanhemelryck, F., De studie van de criminaliteit in het Ancien Régime, Stand van het onderzoek en methode, Bijdragen tot de Geschiedenis, 1973, 56, p. 209-242.

Vanhemelryck, F., Misdaad en straf. Recent onderzoek naar de geschiedenis der criminaliteit, Bijdragen en Mededelingen betreffende de Geschiedenis der Nederlanden, 1978, 93, 2, p. 177-206.

Vries de, J., The Dutch Rural Economy in the Golden Age 1500-1700, New Haven (Conn.), 1974.

Weisser, M.-R., Crime and Punishment in Early Modern Europe, Brighton, 1982 (2nd ed.).

Wijffels, A., L'histoire de la justice: les cours supérieures dans les Anciens Pays-Bas $\left(15^{\mathrm{C}}-18^{\mathrm{e}}\right.$ siècles), Tijdschrift voor Rechtsgeschiedenis-Legal History Review, 61-3 (1993), p. 387400.

Wilson, S., Feuding, Conflict and Banditry in Nineteenth-Century Corsica, Cambridge, 1988.

Wirtz, R., Aspetti della storiografia tedesca sulla criminalità, Quaderni Storici, 1981, 46, p. 212-224.

Zorzi, A., Aspetti e problemi dell'amministrazione della giustizia penale nelle Repubblica frorentina, Archivio storico italiano, 1987, 533, 145, p. 391-453; 1987, 534, p. 527-578.

Zorzi, A., Giustizia criminale e criminalità nell'Italia del tardo medioevo: Studi e prospettive di ricerca, Società e Storia, 1989, 46, p. 923-965.

Zorzi, A., Aspects de la justice criminelle dans les villes italiennes du bas moyen âge, Déviance et Société, 1991a, 15, 4, p. 439-454.

Zorzi, A., Tradizioni storiografiche e studi recenti sulla giustizia nell'Italia del Rinascimento, Cheiron, 1991b, 8, 16, p.27-78.

Zorzi, A., Ordine pubblico e amministrazione della giustizia nelle formazioni politiche toscane tra Tre e Quattrocento, Italia 1350-1450: tra crisi, trasformazione, sviluppo, Pistoia, 1993, p. 419-474.

Zorzi, A., The Judicial System in Florence in the Fourteenth and Fifteenth Centuries, in Dean T., Lowe K.J.P., (eds.), Crime, Society and the Law in Renaissance Italy, Cambridge, 1994, p. 40-58.

Zysberg, A., Les galériens. Vies et destins de 60000 forçats sur les galères de France, 1680 1748, Paris, 1987. 